\title{
4-(4'-Nitrobenzylideneimino)-3-methyl-5-mercapto-1, 2, 4-triazole, A New Chromogenic Reagent for Extractive Spectrophotometric Determination of Copper (II) in Pharmaceutical and Alloy Samples
}

\author{
Abdul B. Shaikha, Umesh B. Barache ${ }^{a}$, Mansing A. Anuse ${ }^{b}$ and Shashikant H. Gaikwad, \\ ${ }^{a}$ Chemistry Research Laboratory, Department of Chemistry, Shri Shivaji Mahavidyalaya, Barshi, Dist. Solapur, (MS) India-413411. \\ ${ }^{b}$ Analytical Chemistry Laboratory, Shivaji University, Kolhapur, (MS) India-416004.
}

Received 16 May 2016, revised 21 June 2016, accepted 29 June 2016.

\begin{abstract}
A simple, selective and rapid extractive spectrophotometric method has been developed for the extraction and determination of $\mathrm{Cu}$ (II) with 4-(4'-nitrobenzylidene imino)-3-methyl-5-mercapto-1, 2, 4-triazole, (NBIMMT). The reagent (NBIMMT) instantly forms stable orange-red coloured complex with $\mathrm{Cu}$ (II) at room temperature and quantitatively extracted in chloroform at pH 6.2. The extracted species exhibits absorption maximum at $470 \mathrm{~nm}$ against reagent blank. The Beer's law was followed in concentration range 4.75 to $16.13 \mathrm{ppm}$ of $\mathrm{Cu}$ (II) and optimum concentration range obtained from Ringbom's plot was found to be 5 to 17.5 ppm. The molar absorptivity and Sandell's sensitivity of $\mathrm{Cu}$ (II)-NBIMMT in chloroform was $2.825 \times 10^{3} \mathrm{~L} \mathrm{~mol}^{-1} \mathrm{~cm}^{-1} \mathrm{and}_{0.0224} \mu \mathrm{g} \mathrm{cm}^{-2}$, respectively. The optimum extraction conditions were evaluated by studying various parameters such as effect of $\mathrm{pH}$, reagent concentration, solvents, shaking time and foreign ions. The use of masking agents enhances the selectivity of method. The composition of the extracted species was determined by Job's method, mole ratio method and verified by $\log -\log$ plot. The ratio of $\mathrm{Cu}$ (II): NBIMMT was found to be 1:2. The proposed method was successfully applied for the determination of Cu (II) in synthetic mixtures, pharmaceutical samples and alloys.
\end{abstract}

KEYWORDS

Alloys, Cu (II), extraction, pharmaceuticals, spectrophotometry.

\section{Introduction}

Copper is widely distributed in nature and it is the third most nutritionally essential trace element in the body after iron and zinc. ${ }^{1}$ The copper is present in all body tissues; however, the liver, the brain, the heart and the kidney contain copper in maximum amount. Copper is absorbed, transported, distributed, stored and excreted in the body. A complex homeostatic process ensures a constant and sufficient supply of micronutrient and simultaneously avoids excess level. ${ }^{2}$ As a micronutrient, copper plays a vital role in many biological systems during cell respiration in the blood of invertebrate animals and in the formation of hemocyanine and important respiratory protein is found in the lymph of most animals belonging to the phyla Mucosa and Arthropoda. ${ }^{3}$ Copper is essential micronutrient which acts as an electron donor or acceptor as its oxidation state fluxes between $\mathrm{Cu}^{+1}$ (cuprous) and $\mathrm{Cu}^{+2}$ (cupric). Copper is an integral part of antioxidant enzyme, copper-zinc superoxide dismutase $(\mathrm{Cu}$, $\mathrm{Zn}-\mathrm{SOD}$ ) and has a role in iron homeostatic as a co-factor in ceruloplasmin. ${ }^{4}$ Copper deficiency causes diseases like anemia, low immune function, osteoporosis, wound healing, arthritis and cardiovascular diseases. The surplus intake of copper leads to diarrhoea, stomach upset, nausea and it also causes jaundice, Wilson disease and tissue injury, etc. Dietary deficiency of copper causes variety of clinical disorders which can be cured by copper therapy. ${ }^{5}$

Due to high electrical conductivity of copper at room temperature, maximum copper production in the world is utilized in electrical industries. ${ }^{6}$ Copper is also used in pipe making, roof * To whom correspondence should be addressed. E-mail: rasayanshg1@ gmail.com sheeting and bronze paints. Pure copper is extensively used for wires, cables, conducting parts and electrical contacts. The copper alloys find extensive applications in automobile radiators, heat exchangers and home-heating systems. Copper is used as fungicide, insecticide and micronutrient fertilizer in agriculture.

Various analytical techniques such as X-ray Fluorescence Spectroscopy, Atomic Absorption Spectrophotometry and Inductively Coupled Plasma-Mass Spectrometry are used for the determination of copper at micro level. These methods are highly sensitive but not selective, involves a number of steps, preconcentration of sample is costly and experts are required to monitor the instrument. Among these techniques, the spectrophotometric methods are easier to handle, more sensitive, rapid and involve less expensive instrumentation. ${ }^{7-17}$ Therefore, the extraction and spectrophotometric determination of trace amount of copper is significant. The phenyl thiosemicarbazones are the extensively used sulphur and nitrogen containing chromogenic reagents which form stable complexes with $\mathrm{Cu}$ (II) and are extracted into organic solvents. The literature survey reveals that only a few phenyl thiosemicarbazones were employed for extractive determination of $\mathrm{Cu}$ (II) ${ }^{18-24}$ Various spectrophotometric methods for determination of $\mathrm{Cu}$ (II) are summarized in the Table 1.

It was revealed from the reported methods that they suffer from disadvantages such as maximum absorbance in UV region and some require surfactant for full colour development, more shaking time, heating of aqueous phase for complexation and synergic extraction.

In the present work, we introduce a new chromogenic reagent 


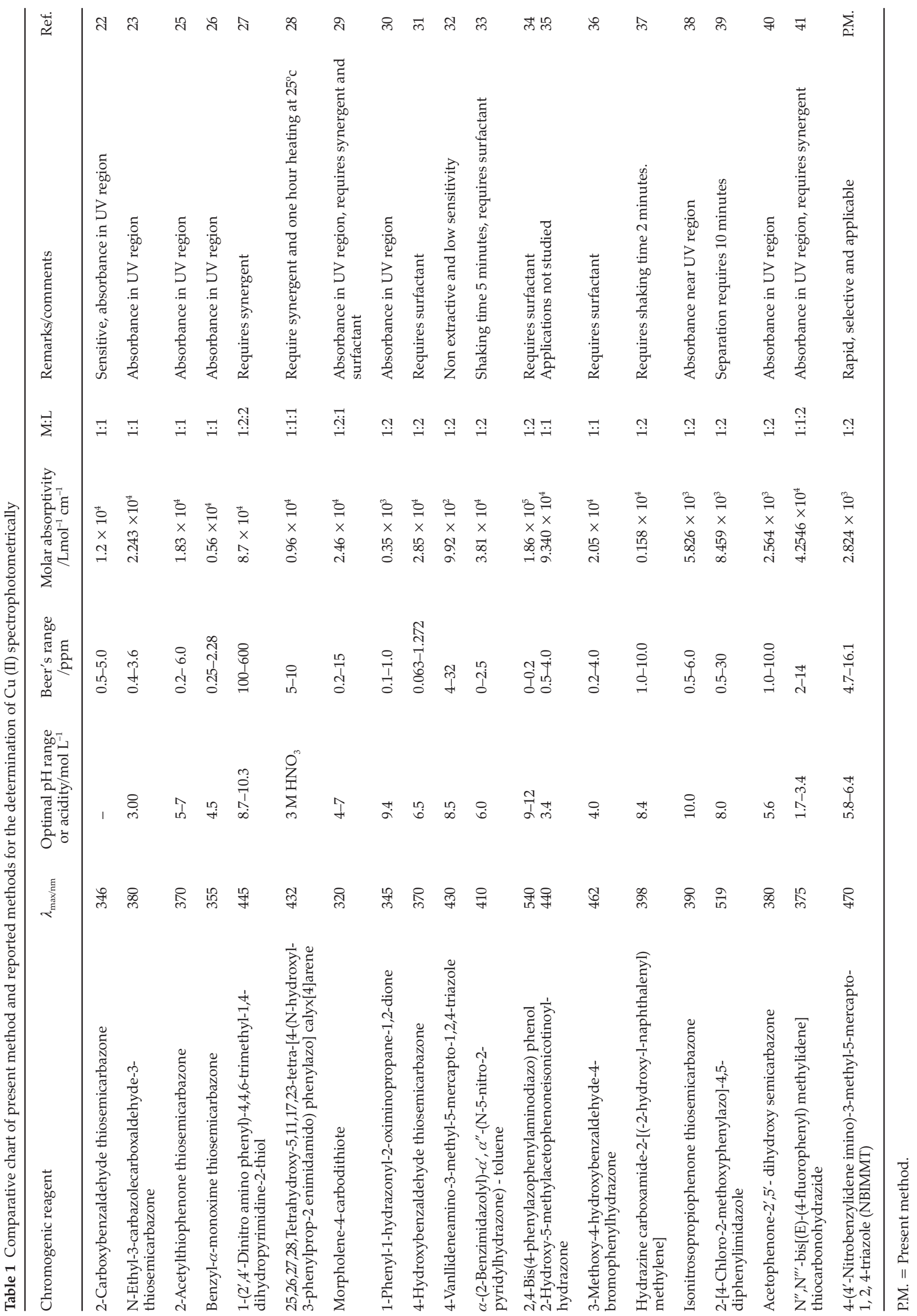




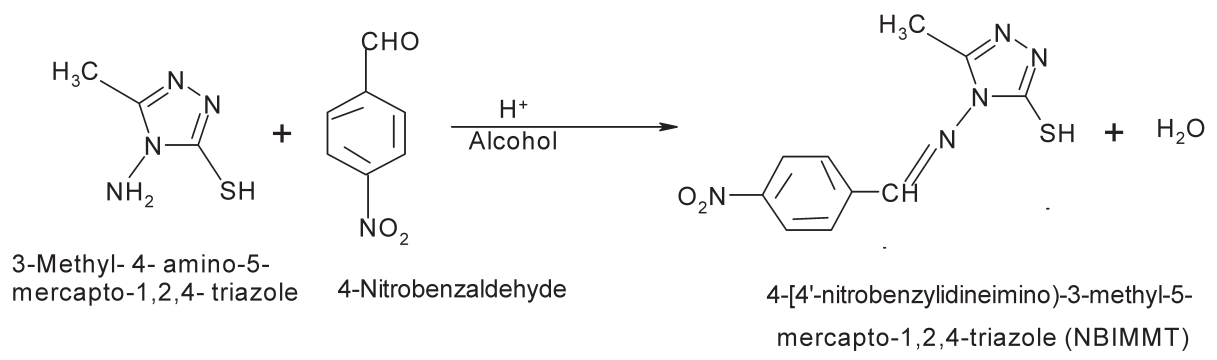

Scheme 1

4-(4'-nitrobenzylidene imino)-3-methyl-5-mercapto-1, 2, 4-triazole, (NBIMMT) and it is applied to develop a new, rapid, selective, simple and reproducible extractive spectrophotometric method for determination of $\mathrm{Cu}$ (II) in pharmaceuticals, synthetic mixtures and alloys. The reagent NBIMMT in chloroform forms orange-red colored complex with $\mathrm{Cu}$ (II) and was extracted quantitatively. The method does not require heating of aqueous phase, surfactant, synergists and extracted complex shows absorbance in visible region.

\section{Experimental}

\subsection{Instrumentation}

Absorbance measurements were carried out using Elico digital spectrophotometer (model SL-159) with $1 \mathrm{~cm}$ matching quartz cells. The $\mathrm{pH}$ measurements were made by using Equiptronics digital $\mathrm{pH}$ meter (model EQ-615). Analytical reagent grade chemicals and reagents were used throughout the study. Calibrated glassware was used for volumetric measurements. A Chemito 203 atomic absorption spectrophotometer was used for comparative purposes.

\subsection{Reagents}

Preparation and characterization of 4-(4'-nitrobenzylidene imino)-3-methyl-5-mercapto-1, 2, 4-triazole (NBIMMT). ${ }^{32,42}$ The reagent NBIMMT was prepared by simple condensation of 3-methyl-4-amino-5-mercapto-1, 2, 4-triazole (2.6 g, $0.02 \mathrm{M})$ with 4-nitrobenzaldehyde (3.029 g, 0.02 M). The mixture of 3-methyl4-amino-5-mercapto-1, 2, 4-triazole and 4-nitrobenzaldehyde in $100 \mathrm{~mL}$ of ethanol containing 3 drops of glacial acetic acid was refluxed for 3-4 hours. The product was separated and recrystallized from hot ethanol. On cooling faint yellow needles were obtained. The Scheme 1 shows the reaction for preparation of NBIMMT.

By using thin layer chromatography, the purity of the NBIMMT was checked. The melting point of ligand was $224^{\circ} \mathrm{C}$ and structure was confirmed by using NMR and IR spectra.

${ }^{1} \mathrm{H}$ NMR (400 MHz, DMSO, $\left.\Delta \mathrm{ppm}\right): 2.39$ (s, 3H, $\left.-\mathrm{CH}_{3}\right), 8.17$ (d, $2 \mathrm{H}, \mathrm{Ar}-\mathrm{H}, \mathrm{J}=8.6 \mathrm{~Hz}), 8.36$ (d, 2H, Ar-H, J = 8.6 Hz), 10.40 (s, 1H, $-\mathrm{N}=\mathrm{CH}), 13.82(\mathrm{~s}, 1 \mathrm{H},-\mathrm{SH})$.

IR (KBr, cm $\left.{ }^{-1}\right) 3370(\mathrm{SH}), 1600,1590(\mathrm{C}=\mathrm{C})$, 1530, $1340\left(\mathrm{NO}_{2}\right)$.

By dissolving $3.96 \mathrm{~g}$ of cupric sulphate pentahydrate $\left(\mathrm{CuSO}_{4} .5 \mathrm{H}_{2} \mathrm{O}\right.$, Merck) in water, a standard stock solution of $\mathrm{Cu}$ (II) was prepared. The stock solution was standardized titrimetrically by known method. ${ }^{43}$ The working standard of $\mathrm{Cu}$ (II) solution was prepared by appropriate dilution of standard stock solution with water.

A reagent solution $(0.01 \mathrm{M})$ was prepared in chloroform by dissolving $0.263 \mathrm{~g}$ NBIMMT in $100 \mathrm{~mL}$ volumetric flask. The fresh reagent solution was used as and when required. Other standard solutions of foreign ions were prepared by dissolving requisite quantities of their salt in water. Various synthetic mixtures containing $\mathrm{Cu}$ (II) were prepared by combining it with commonly associated metal ions in definite composition. ${ }^{44}$ Doubly distilled water was used throughout the experiments. The buffer of $\mathrm{pH} 6.2$ was prepared by mixing appropriate volume of $0.1 \mathrm{M} \mathrm{NaOH}$ and $0.1 \mathrm{M} \mathrm{KH}_{2} \mathrm{PO}_{4}$ solutions. ${ }^{45}$

\subsection{Recommended Procedure}

Sample solution (1 mL) containing $100 \mathrm{ppm}$ of $\mathrm{Cu}$ (II) was diluted with phosphate buffer ( $\mathrm{pH}$ 6.2) up to the mark in $25 \mathrm{~mL}$ volumetric flask. The solution was transferred into $125 \mathrm{~mL}$ separating funnel, followed by addition of $10 \mathrm{~mL} 0.01 \mathrm{M}$ NBIMMT in chloroform. The two phases equilibrated for $30 \mathrm{~s}$. The organic extract was collected over anhydrous sodium sulphate $(1 \mathrm{~g})$ to remove the traces of water and then it was transferred in $10 \mathrm{~mL}$ volumetric flask and diluted up to the mark with chloroform. The absorbance of the extracted complex was measured at $470 \mathrm{~nm}$ against reagent blank. The reagent blank was prepared in the same way without taking $\mathrm{Cu}$ (II). A calibration curve was prepared and unknown amount of $\mathrm{Cu}$ (II) was determined from the calibration curve.

The percentage extraction (\% E) and metal distribution ratio (D) were calculated according to Equations (1) and (2), respectively. ${ }^{27}$

$$
\begin{aligned}
& \% E=\frac{[M]_{\text {org. }}}{[M]_{\text {aq.init. }}} \times 100 \\
& D=\frac{[M]_{\text {org. }}}{[M]_{\text {aq. }}}
\end{aligned}
$$

where, $[M]_{\text {aq.init. }}$ represents the initial concentration of metal in aqueous phase, $[M]_{\text {aq. }}$ and $[M]_{\text {org. }}$ are the total concentrations of metal ion in aqueous and organic phases after equilibrium, respectively.

\section{Results and Discussion}

\subsection{Spectral Characteristics}

Figure 1 shows absorption spectra of the $\mathrm{Cu}$ (II)-NBIMMT complex at pH 6.2 against reagent blank. The absorption measurements were made in the spectral range $360-750 \mathrm{~nm}$. The absorbance curves indicate that the orange-red coloured $\mathrm{Cu}$ (II)-NBIMMT complex in organic phase exhibits absorbance maximum at $470 \mathrm{~nm}$. The absorbance of reagent, NBIMMT at $470 \mathrm{~nm}$ is negligibly small against chloroform blank, therefore the spectrophotometric measurements were made at $470 \mathrm{~nm}$ against the reagent blank and $\mathrm{Cu}$ (II) was determined.

\subsection{Effect of $\mathrm{pH}$}

Change in $\mathrm{pH}$ affected the complexation of $\mathrm{Cu}$ (II)-NBIMMT. Therefore, the absorbance of complex was studied between $\mathrm{pH} 1$ to 10 by using dilute $\mathrm{HCl}$ and $\mathrm{NaOH}$ solutions. The absorbance values of extracted complex were measured. The maximum absorbance was obtained in the $\mathrm{pH}$ range 5.8 to 6.4. Beyond this $\mathrm{pH}$ range, the observed absorbance values were lower. $\mathrm{pH}$ effect 


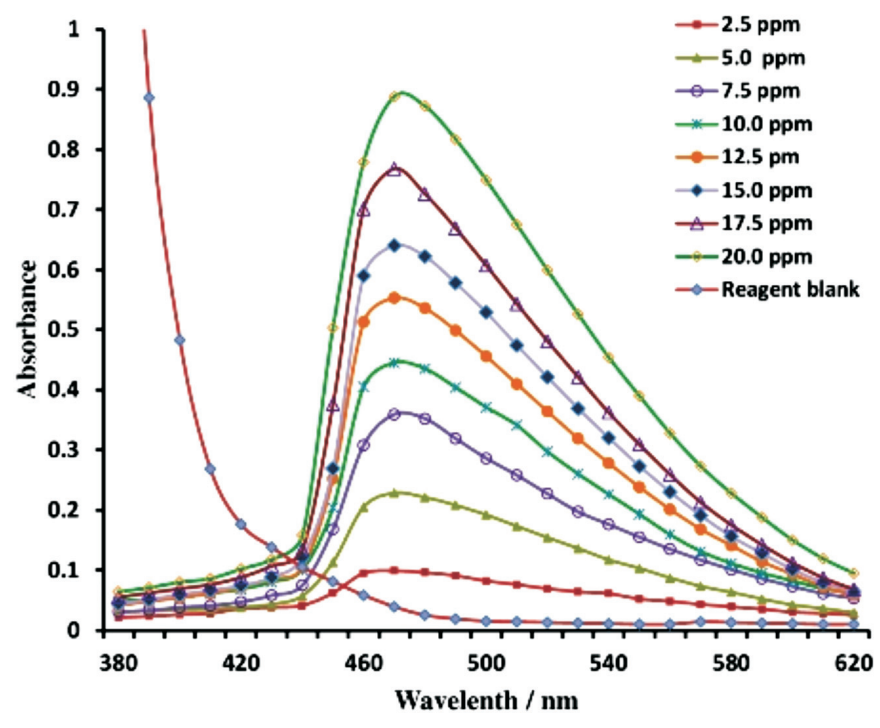

Figure 1 Absorbance curves for $\mathrm{Cu}$ (II)-NBIMMT complex and the absorbance of reagent blank: $\mathrm{Cu}$ (II) $=2.5-20 \mathrm{ppm}$; Phosphate buffer $\mathrm{pH}$ $=6.2 ; \mathrm{NBIMMT}=10 \mathrm{~mL} 0.01 \mathrm{M}$ in chloroform.

was also studied by using acetate and phosphate buffer solutions. The values of absorbance observed using buffer solutions coincide with the absorbance values obtained by adjusting the $\mathrm{pH}$ of aliquots by $\mathrm{pH}$ meter. Therefore, phosphate buffer of $\mathrm{pH}$ 6.2 was used conveniently for all the subsequent studies which do not require $\mathrm{pH}$ adjustment (Fig. 2).

\subsection{Choice of Solvent}

Various organic solvents were tested for the extraction of $\mathrm{Cu}$ (II)-NBIMMT complex. It was found that the absorbance values at $\lambda_{\max } 470 \mathrm{~nm}$ increased in the order: carbon tetrachloride $<$ MIBK $<$ xylene $<$ n-butanol $<1$, 2,-dichloroethane $<$ toluene $<$ benzene $=$ chloroform (Fig. 3). Benzene is carcinogenic hence chloroform was recommended for further studies.

\subsection{Effect of NBIMMT Concentration and Stability of Complex}

The effect of reagent concentration was investigated by measuring absorbance of solution containing $10 \mathrm{ppm} \mathrm{Cu}$ (II)

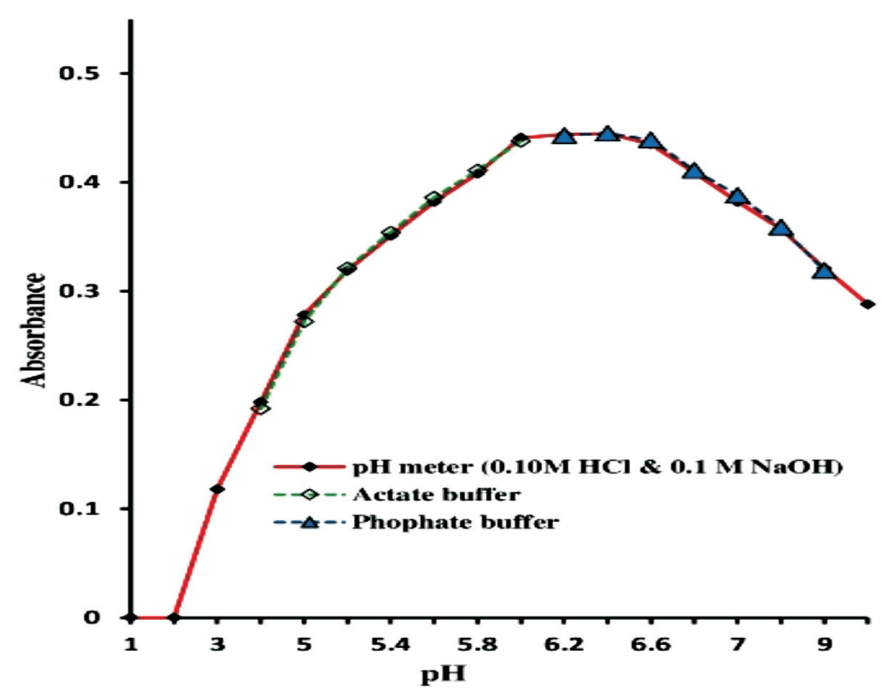

Figure 2 Effect of $\mathrm{pH}$ on extraction $\mathrm{Cu}$ (II)-NBIMMT complex: $\mathrm{Cu}$ (II) = $10 \mathrm{ppm} ; \mathrm{pH}=1-10 ; \mathrm{NBIMMT}=10 \mathrm{~mL} 0.01 \mathrm{M}$ in chloroform; $\lambda_{\max }=$ $470 \mathrm{~nm}$

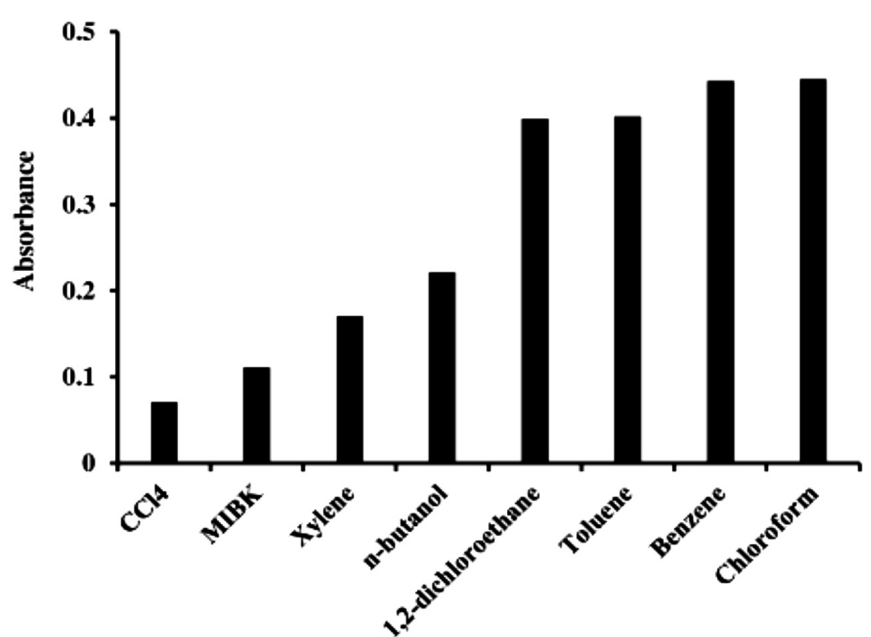

Solvent

Figure 3 Effect of solvent on Cu (II)-NBIMMT complex: $\mathrm{Cu}$ (II) $=10$ ppm; phosphate buffer $\mathrm{pH}=6.2$; NBIMMT $=10 \mathrm{~mL} 0.01 \mathrm{M} ; \lambda_{\max }=$ $470 \mathrm{~nm}$

constant and NBIMMT of various concentrations in $10 \mathrm{~mL}$ chloroform at $470 \mathrm{~nm}$. It was found that about thirty-two-fold molar excess of reagent over $\mathrm{Cu}$ (II) was required to complete the complexation (Fig. 4). It was also found that there was no adverse effect of excess reagent concentration. Therefore sixtyfold excess of reagent was suggested in general procedure to ensure complete complexation of $\mathrm{Cu}$ (II). The orange-red colour of $\mathrm{Cu}$ (II)-NBIMMT complex was found to be stable for more than 24 hours.

\subsection{Effect of Shaking Time}

Extraction of $\mathrm{Cu}$ (II) by 0.01M NBIMMT in chloroform was found to be very rapid. Percentage of extraction remained unaffected, when the shaking time was varied from $5 \mathrm{~s}$ to $30 \mathrm{~min}$. In present investigation $20 \mathrm{~s}$ shaking time was recommended for quantitative extraction of $\mathrm{Cu}$ (II) in organic phase.

\subsection{Validity of Beer's Law, Sensitivity}

The system adheres to Beer's law in range 4.75 to $16.13 \mathrm{ppm}$ (Fig. 5) of $\mathrm{Cu}$ (II) with optimum concentration range 5.0 to

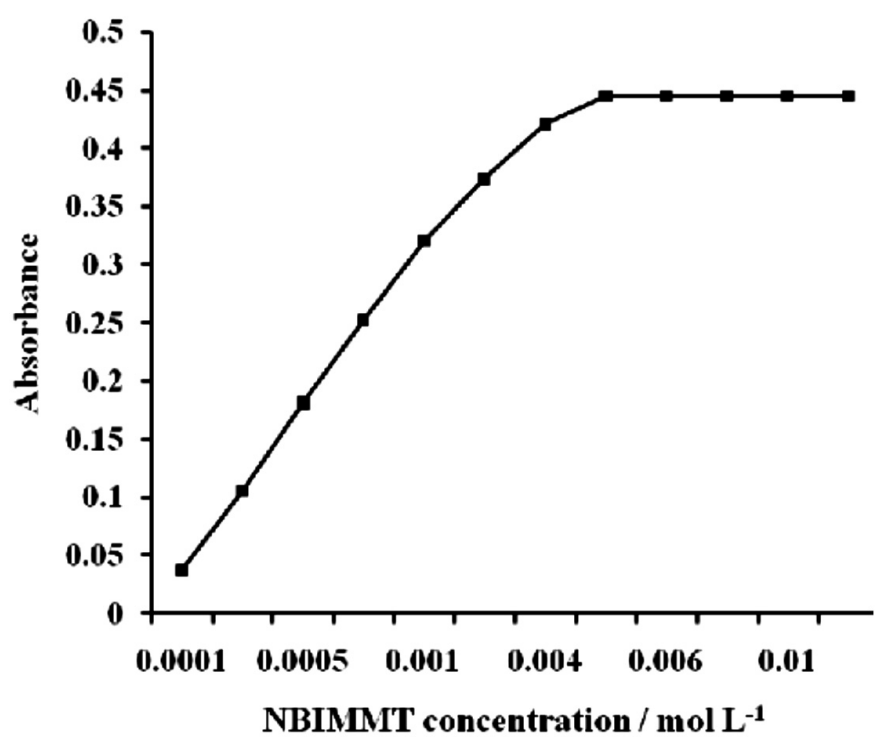

Figure 4 Effect of reagent concentration: $\mathrm{Cu}$ (II) $=10 \mathrm{ppm}$; phosphate buffer $\mathrm{pH}=6.2$; NBIMMT in $10 \mathrm{~mL}$ chloroform; $\lambda_{\max }=470 \mathrm{~nm}$ 


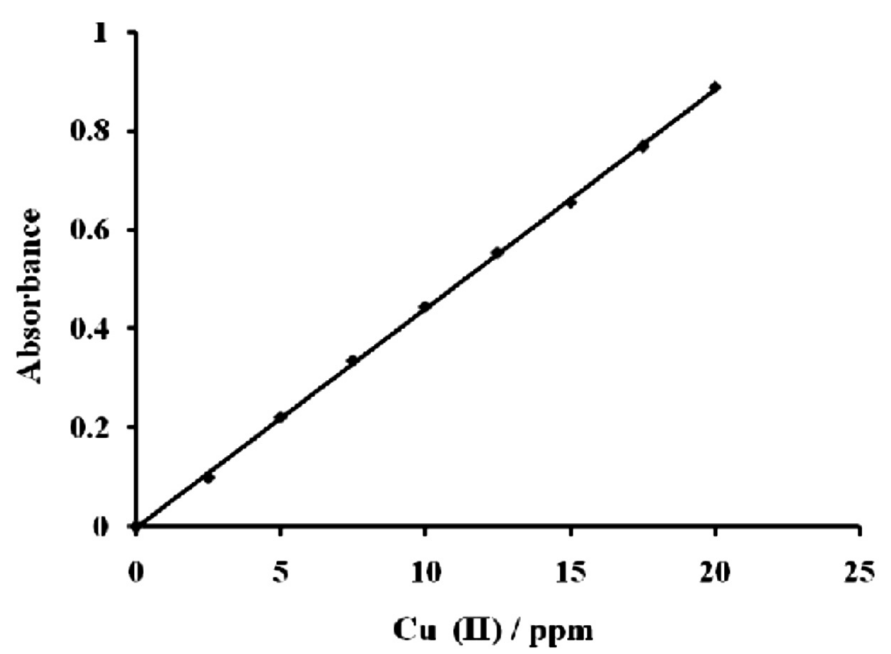

Figure 5 Validity of Beer's law for $\mathrm{Cu}$ (II)-NBIMMT complex: $\mathrm{Cu}$ (II) = 2.5-20 ppm; phosphate buffer $\mathrm{pH}=6.2$; NBIMMT $=10 \mathrm{~mL} 0.01 \mathrm{M}$ in chloroform; $\lambda_{\max }=470 \mathrm{~nm}$.

$17.5 \mathrm{ppm}$ of the metal as evaluated from a Ringbom's curve, a plot of $\log [\mathrm{Cu}$ (II)] versus \% T (Fig. 6). The plot shows sigmoid curve. The steepest portion of the curve indicates the optimum concentration range where error is minimal. ${ }^{46-47}$ The molar absorptivity calculated from Beer's law over the range studied was $2.825 \times 10^{3} \mathrm{~L} \mathrm{~mol}^{-1} \mathrm{~cm}^{-1}$ and Sandell's sensitivity was $0.02247 \mu \mathrm{g} \mathrm{cm}^{-2}$. These molar absorptivity and Sandell's sensitivity values indicate that the method is moderately sensitive. ${ }^{48}$

\subsection{Stoichiometry of the Complex}

The stoichiometry of $\mathrm{Cu}$ (II)-NBIMMT complex was confirmed by Job's continuous variation, mole ratio and log-log plot methods.

\subsubsection{Job's Continuous Variation Method}

Equimolar solutions of $\mathrm{Cu}$ (II) and NBIMMT in chloroform were used. $\mathrm{Cu}$ (II) solution was adjusted to $\mathrm{pH} 6.2$ with phosphate buffer solution in a total volume of $25 \mathrm{~mL}$ and transferred to $125 \mathrm{~mL}$ separating funnel. NBIMMT was mixed in complementary proportions containing varying amount of reagent in $10 \mathrm{~mL}$ chloroform. The absorbance of an organic extract was measured at $470 \mathrm{~nm}$ against the reagent blank prepared in similar way without taking $\mathrm{Cu}$ (II). The plot of absorbance versus mole fraction $(\mathrm{M} / \mathrm{M}+\mathrm{L})$ indicates that the formation of complex of $\mathrm{Cu}$ (II) with NBIMMT in the ratio of 1:2 (Fig. 7).

\subsubsection{Mole Ratio Method}

Equimolar solution of $\mathrm{Cu}$ (II) and NBIMMT were used. A series of solutions were prepared by keeping the concentration of $\mathrm{Cu}$ (II) constant $(0.001573 \mathrm{M}, 1 \mathrm{~mL})$. The volume of solution was adjusted to $25 \mathrm{~mL}$ by phosphate buffer of $\mathrm{pH} 6.2$ and varying amount of reagent in chloroform $(0.001573 \mathrm{M}, 0.5-5.0 \mathrm{~mL})$ were used for extraction of $\mathrm{Cu}$ (II)-NBIMMT complex by adjusting total volume $10 \mathrm{~mL}$ with chloroform. The absorbance was measured at $470 \mathrm{~nm}$ against corresponding reagent blank. The graph of absorbance versus the molar ratio (L/M) was plotted and a break was observed where the $\mathrm{Cu}$ (II) to NBIMMT ratio was 1:2 (Fig. 8).

\subsection{3. $\log -\log$ Plot}

In this method, concentration of $\mathrm{Cu}$ (II) was kept constant and buffer of $\mathrm{pH} 4.0$ was added to make volume $25 \mathrm{~mL}$. The NBIMMT of various concentrations was added and finally the volume of organic phase was made up to $10 \mathrm{~mL}$. The absorbance

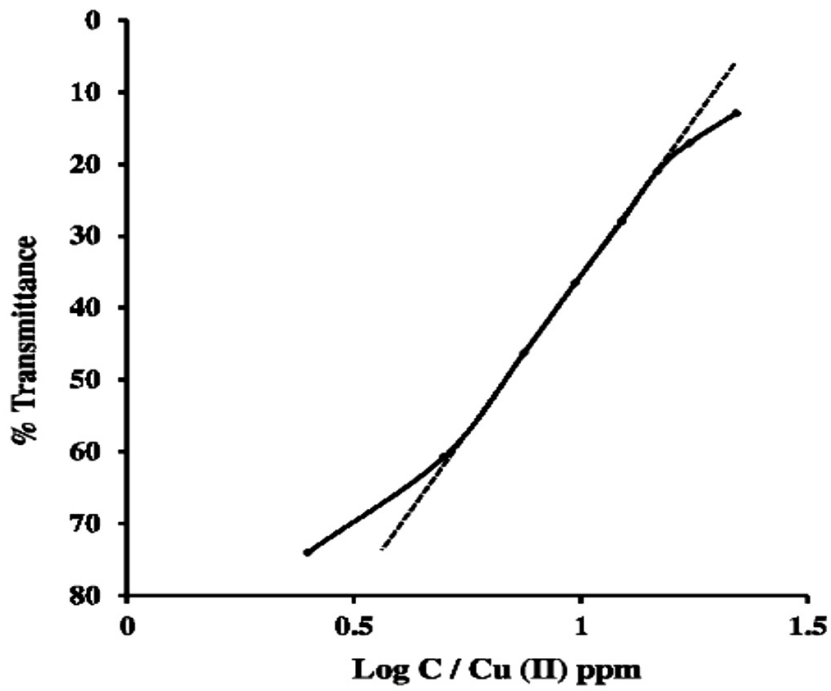

Figure 6 Ringbom's plot of $\mathrm{Cu}$ (II)-NBIMMT complex: $\mathrm{Cu}$ (II) = 2.5-20 ppm; phosphate buffer $\mathrm{pH}=6.2$; NBIMMT $=10 \mathrm{~mL} 0.01 \mathrm{M}$ in chloroform; $\lambda_{\max }=470 \mathrm{~nm}$.

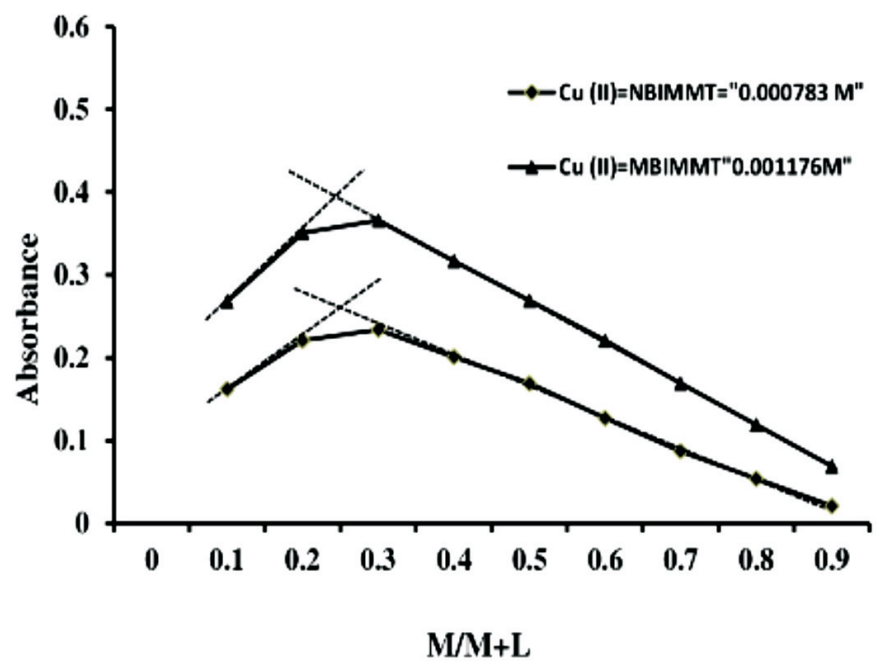

Figure 7 Job's plot for composition of Cu (II)-NBIMMT complex: [M] = $[\mathrm{L}]=0.000783 \mathrm{M}, 0.001176 \mathrm{M}$ : NBIMMT in chloroform; phosphate buffer of $\mathrm{pH}=6.2 ; \lambda_{\max }=470 \mathrm{~nm}$.

of coloured organic phases was recorded at $470 \mathrm{~nm}$ against respective reagent blank. The nature of extracted $\mathrm{Cu}(\mathrm{II})$ NBIMMT complex was asserted by plotting graph of $\log \mathrm{D}_{[\mathrm{Cu} \text { (II)] }}$ against $\log \mathrm{C}_{\text {(NBIMMT) }}$. The plot is linear having slope 1.6 (Fig. 9).

Therefore the composition of extracted species was found to be 1:2, Cu (II): NBIMMT. Scheme 2 shows the probable extracted species of $\mathrm{Cu}$ (II) with NBIMMT.

\subsection{Effect of Foreign Ions}

To find selectivity of proposed method, the study was carried out for the determination of $\mathrm{Cu}$ (II) in presence of higher concentration of foreign ion. The tolerance limit of the ions shows minimum deviation $( \pm 2 \%)$ in absorbance. The interference of various cations was removed by using suitable masking agents (Table 2).

\section{Applications}

\subsection{Determination of $\mathrm{Cu}$ (II) in Synthetic Mixtures}

The synthetic mixtures of definite compositions were prepared by taking $100 \mathrm{ppm} \mathrm{Cu}$ (II) and associated metal ions of 


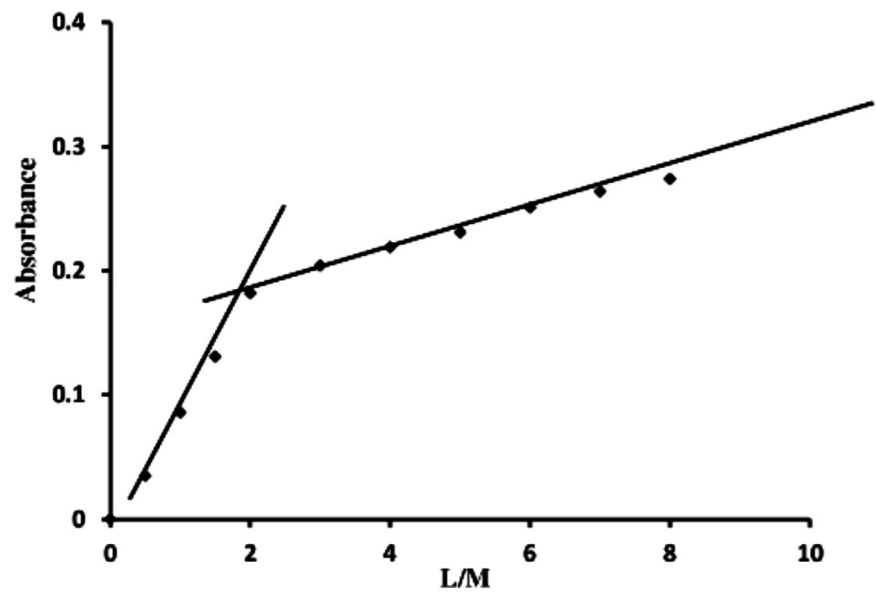

Figure 8 Mole ratio method: $\mathrm{Cu}(\mathrm{II})=0.001573 \mathrm{M}$; NBIMMT $=$ $0.001573 \mathrm{M}$ in chloroform; phosphate buffer $\mathrm{pH}=6.2 ; \lambda_{\max }=470 \mathrm{~nm}$

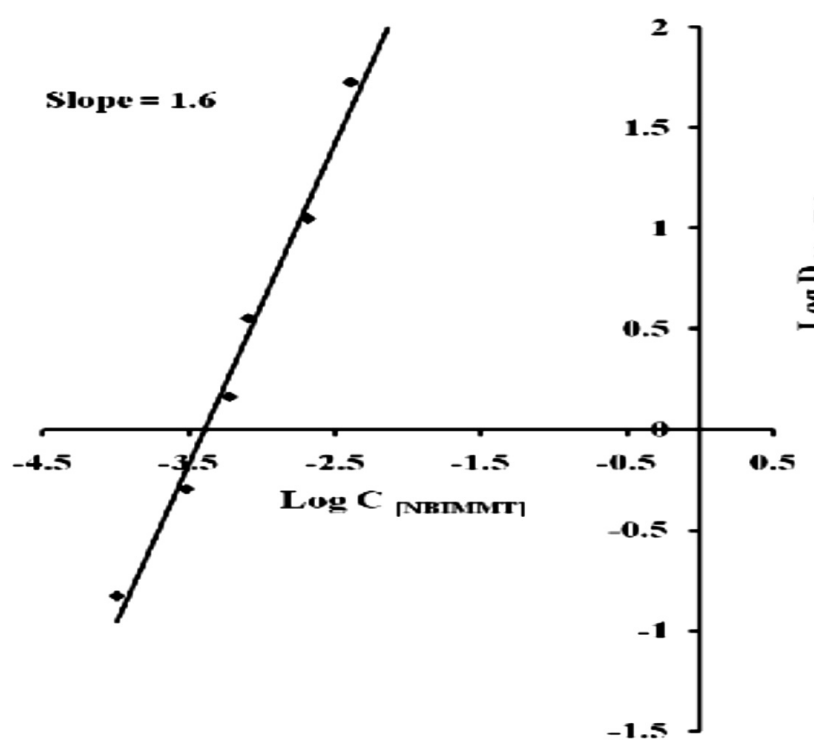

Figure $9 \log \mathrm{D}_{[\mathrm{Cu}(\mathrm{II}]]}$ versus $\log \mathrm{C}_{[\mathrm{NBIMMT}]}$ curve for determination of composition of complex: $\mathrm{Cu}$ (II) $=10 \mathrm{ppm}$; phosphate buffer $\mathrm{pH}=4.0$; NBIMMT in chloroform; $\lambda_{\max }=470 \mathrm{~nm}$

known concentrations. ${ }^{44}$ The present method was applied for determination of $\mathrm{Cu}$ (II) in these synthetic mixtures by employing the recommended procedure. The results obtained were in conformity with amount of $\mathrm{Cu}$ (II) taken (Table 3).

\subsection{Determination of $\mathrm{Cu}$ (II) from Alloys}

In order to check the analytical applicability of present method, Cu (II) was determined from standard alloy samples. Alloy $100 \mathrm{mg}$ was dissolved in aquaregia $(5 \mathrm{~mL})$, heated on hotplate to almost moist dryness and the nitrate was removed by
Table 2 Effect of foreign ions on the extractive spectrophotometric determination of $\mathrm{Cu}$ (II)

\begin{tabular}{|c|c|c|}
\hline Foreign ions & Added as & Amount tolerated/mg \\
\hline $\mathrm{Ni}(\mathrm{II})$ & $\mathrm{Ni}\left(\mathrm{NO}_{3}\right)_{2} \cdot 6 \mathrm{H}_{2} \mathrm{O}$ & 5.0 \\
\hline $\mathrm{V}(\mathrm{V})$ & $\mathrm{V}_{2} \mathrm{O}_{5}$ & 5.0 \\
\hline $\mathrm{Hg}(\mathrm{II})^{\mathrm{a}}$ & $\mathrm{HgCl} 2$ & 5.0 \\
\hline Co $(\text { II })^{\text {a }}$ & $\mathrm{CoCl}_{2} \cdot 6 \mathrm{H}_{2} \mathrm{O}$ & 3.0 \\
\hline $\mathrm{Mg}$ (II) & $\mathrm{MgCl}_{2}$ & 2.0 \\
\hline $\mathrm{Ba}$ (II) & $\mathrm{BaCl}_{2}$ & 2.0 \\
\hline $\mathrm{Ca}$ (II) & $\mathrm{CaCl}_{2}$ & 2.0 \\
\hline $\mathrm{W}(\mathrm{VI})$ & $\mathrm{Na}_{2} \mathrm{WO}_{4} \cdot \mathrm{H}_{2} \mathrm{O}$ & 1.0 \\
\hline $\mathrm{Fe}$ (III) & $\mathrm{FeCl}_{3}$ & 1.0 \\
\hline $\mathrm{Sb}$ (III) & $\mathrm{SbCl}_{3}$ & 1.0 \\
\hline $\mathrm{Pb}$ (II) & $\mathrm{Pb}\left(\mathrm{NO}_{3}\right)_{2}$ & 1.0 \\
\hline $\mathrm{Zr}(\mathrm{IV})$ & $\mathrm{ZrCl}_{4}$ & 1.0 \\
\hline $\mathrm{Ti}$ (II) & $\mathrm{TiCl}_{2}$ & 1.0 \\
\hline $\operatorname{Mn}(\mathrm{II})^{\mathrm{b}}$ & $\mathrm{MnCl}_{2} \cdot 4 \mathrm{H}_{2} \mathrm{O}$ & 1.0 \\
\hline $\mathrm{Zn}(\mathrm{II})^{\mathrm{b}}$ & $\mathrm{ZnCl} 2$ & 1.0 \\
\hline $\mathrm{Fe}(\mathrm{II})$ & $\mathrm{FeSO}_{4}$ & 0.5 \\
\hline $\mathrm{Mo}(\mathrm{VI})$ & $\left(\mathrm{NH}_{4}\right)_{2} \mathrm{Mo}_{7} \mathrm{O}_{24} \cdot 2 \mathrm{H}_{2} \mathrm{O}$ & 0.5 \\
\hline $\mathrm{Te}(\mathrm{IV})$ & $\mathrm{Na}_{2} \mathrm{TeO}_{3}$ & 0.5 \\
\hline $\mathrm{Ru}$ (III) & $\mathrm{RuCl}_{3} \cdot 6 \mathrm{H}_{2} \mathrm{O}$ & 0.5 \\
\hline Mn (VII) & $\mathrm{KMnO}_{4}$ & 0.5 \\
\hline $\mathrm{Cr}(\mathrm{VI})$ & $\mathrm{K}_{2} \mathrm{Cr}_{2} \mathrm{O}_{7}$ & 0.5 \\
\hline $\mathrm{Au}(\mathrm{III})^{\mathrm{a}}$ & $\mathrm{HAuCl}_{4} \cdot 4 \mathrm{H}_{2} \mathrm{O}$ & 0.5 \\
\hline $\mathrm{Pd}(\mathrm{II})^{\mathrm{d}}$ & $\mathrm{PdCl}_{2}$ & 0.5 \\
\hline $\mathrm{Ag}(\mathrm{I})^{\mathrm{e}}$ & $\mathrm{AgNO}_{3}$ & 0.5 \\
\hline Sn (II) ${ }^{c}$ & $\mathrm{SnCl}_{2} \cdot 2 \mathrm{H}_{2} \mathrm{O}$ & 0.5 \\
\hline $\mathrm{Cd}(\mathrm{II})^{\mathrm{a}}$ & $\mathrm{CdCl}_{2} \cdot 2 \mathrm{H}_{2} \mathrm{O}$ & 0.5 \\
\hline $\mathrm{Al}(\mathrm{III})^{\mathrm{c}}$ & $\mathrm{AlCl}_{3}$ & 0.5 \\
\hline Os (VIII) ${ }^{c}$ & $\mathrm{OsO}_{4}$ & 0.5 \\
\hline Bromide & $\mathrm{KBr}^{4}$ & 100 \\
\hline Thiocyanate & $\mathrm{NH}_{4} \mathrm{SCN}$ & 100 \\
\hline Acetate & Sod. acetate & 100 \\
\hline Iodide & $\mathrm{KI}$ & 100 \\
\hline Succinate & Succinic acid & 50 \\
\hline Tartarate & Sod. Pot. tartarate & 100 \\
\hline Sulphate & $\mathrm{Na}_{2} \mathrm{SO}_{4}$ & 100 \\
\hline Thiourea & Thiourea & 100 \\
\hline Nitrate & $\mathrm{NaNO}_{3}$ & 100 \\
\hline Thiosulphate & $\mathrm{Na}_{2} \mathrm{~S}_{2} \mathrm{O}_{3}$ & 100 \\
\hline Fluoride & $\mathrm{NaF}$ & 20 \\
\hline
\end{tabular}

${ }^{\text {a }}$ Masked with $50 \mathrm{mg}$ thiosulphate.

${ }^{\mathrm{b}}$ Masked with $50 \mathrm{mg}$ tartrate.

${ }^{c}$ Masked with $50 \mathrm{mg}$ succinate.

d Masked with $50 \mathrm{mg}$ thiocyanate.

e Masked with $50 \mathrm{mg}$ iodide.

using concentrated $\mathrm{HCl}$. Residue was filtered and filtrate was made up to $100 \mathrm{~mL}$ with doubly distilled water. Suitable aliquot of diluted solutions were taken and determined by present method. The results obtained by present method were consistent with that of AAS (Table 4).<smiles></smiles> 
Table 3 Determination of $\mathrm{Cu}$ (II) in a synthetic mixtures. Phosphate buffer $\mathrm{pH}=6.2, \mathrm{NBIMMT}=10 \mathrm{~mL} 0.01 \mathrm{Min}$ chloroform, $\lambda_{\max }=470 \mathrm{~nm}$.

\begin{tabular}{|c|c|c|}
\hline Composition (ppm) & Recovery * & ${ }^{\#} \mathrm{RSD} \%$ \\
\hline $\mathrm{Cu}$ (II), 100; Fe (III), 50; Ni (II), 50 & 99.7 & 0.12 \\
\hline $\mathrm{Cu}$ (II), 100; Pb (II), 50; Ni (II), 50 & 99.8 & 0.10 \\
\hline $\mathrm{Cu}$ (II,) 100; Pb (II), 50; Sn (II), 50 & 99.9 & 0.05 \\
\hline $\mathrm{Cu}$ (II), 100; Mn (II), 50; Ni (II), 50 & 99.9 & 0.07 \\
\hline $\mathrm{Cu}$ (II), 100; $\mathrm{Au}$ (III), 50; Ni (II), 50 & 99.8 & 0.18 \\
\hline $\mathrm{Cu}$ (II), 100; $\mathrm{Co}$ (II), 50; Pb (II), 50 & 99.8 & 0.13 \\
\hline $\mathrm{Cu}$ (II), 100; Zn (II), 50; Sn (II), 50 & 99.7 & 0.12 \\
\hline $\mathrm{Cu}$ (II), 100; Fe (III), 50; Co (II), 50 & 99.9 & 0.07 \\
\hline $\mathrm{Cu}$ (II), 100; Ag (I), 50; Au (III), 50 & 99.8 & 0.09 \\
\hline $\mathrm{Cu}$ (II), 100; Zn (II), 50; Cd (II), 50 & 99.8 & 0.07 \\
\hline $\mathrm{Cu}(\mathrm{II}), 100 ; \mathrm{Pb}(\mathrm{II}), 50 ; \mathrm{V}(\mathrm{V}), 50$ & 99.9 & 0.10 \\
\hline
\end{tabular}

* Average of five determinations; ${ }^{*}$ Relative standard deviation

Table 4 Determination of $\mathrm{Cu}$ (II) from alloys. Phosphate buffer $\mathrm{pH}=6.2, \mathrm{NBIMMT}=10 \mathrm{~mL} 0.01 \mathrm{M}$ in chloroform, $\lambda_{\max }=470 \mathrm{~nm}$.

\begin{tabular}{lcrrr}
\hline Composition of alloy (\%) & \multirow{2}{*}{ Certified values of Cu (II)/\% } & \multicolumn{2}{c}{ Amount of Cu (II) found/\% } \\
\cline { 3 - 4 } & & P.M. ${ }^{*}$ RSD $\%$ & AAS method \\
\hline Gun metal (Kamini Industries supplies Standards, India) & 84.90 & 82.1 & 82.4 & 0.32 \\
Brass (Shibh Chemi Incorporate, Mumbai) & 56.26 & 54.8 & 54.9 & 0.10 \\
Cu-Ag-Au Alloy & 35.00 & 35.0 & 35.1 & 0.05 \\
Cu-Ag-Au Alloy & 50.00 & 49.6 & 49.8 \\
\hline
\end{tabular}

* Present method, average of five determinations; ${ }^{\#}$ Relative standard deviation.

\subsection{Determination of $\mathrm{Cu}$ (II) from Pharmaceutical Samples}

The pharmaceutical samples such as Supradyn, Eldervit 20 and Antoxid were selected for determination of $\mathrm{Cu}$ (II). A known weight of sample was dissolved in $5 \mathrm{~mL}$ aquaregia and evaporated to moist dryness on hot plate. The residue was dissolved in $2 \mathrm{~mL} \mathrm{1:1} \mathrm{HCl}$ and filtered through Whatman filter paper No. 1 . The filtrate was diluted with water up to $10 \mathrm{~mL}$ in volumetric flask. The analysis of $\mathrm{Cu}$ (II) was carried out by recommended procedure and results were compared with result obtained by atomic absorption spectrophotometer (Table 5).

\section{Conclusion}

The 4-(4'-nitrobezylideneimino)-3-methyl-5-mercapto-1,2,4triazole was synthesized and an extractive spectrophotometric method was developed for determination of $\mathrm{Cu}$ (II) at microgram level by using phosphate buffer solution. Equilibration time is very less; method is rapid, selective, reproducible and reliable. The method is applicable for determination of $\mathrm{Cu}$ (II) from synthetic mixtures, pharmaceutical samples and alloys. The results obtained are in good agreement with the certified values and comparable to those obtained by known methods.

Table 5 Determination of $\mathrm{Cu}(\mathrm{II})$ from pharmaceutical samples. Phosphate buffer $\mathrm{pH}=6.2 ; \mathrm{NBIMMT}=10 \mathrm{~mL} 0.01 \mathrm{Min}$ chloroform; $\lambda_{\max }=470 \mathrm{~nm}$.

\begin{tabular}{|c|c|c|c|c|c|}
\hline Sample & Composition & $\begin{array}{l}\text { Certified values } \\
\text { of } \mathrm{Cu}(\mathrm{II}) \\
\quad / \mathrm{mg} \mathrm{tab}^{-1}\end{array}$ & $\begin{array}{c}\text { Amount of } \mathrm{Cu} \\
\text { (II) found } \\
/ \mathrm{mg} \mathrm{tab}^{-1} \\
\text { (Present method }^{*} \text { ) }\end{array}$ & $\begin{array}{l}\text { Amount of } \\
\mathrm{Cu} \text { (II) found } \\
/ \mathrm{mg} \mathrm{tab}^{-1} \text { ( AAS) }\end{array}$ & 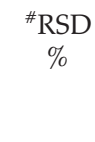 \\
\hline $\begin{array}{l}\text { Supradyn } \\
\text { (Piramal } \\
\text { Health Care } \\
\text { Ltd. Mahad) }\end{array}$ & $\begin{array}{l}\text { Zinc sulphate } 2.20 \mathrm{mg} \text {, sodium molybdate } 0.25 \\
\mathrm{mg} \text {, sodium borate } 0.88 \mathrm{mg} \text {, magnesium oxide } \\
6.0 \mathrm{mg} \text {, calcium phosphate } 129 \mathrm{mg} \text {, } \\
\text { ferroussulphate } 32.04 \mathrm{mg} \text {, manganese sulphate } \\
\text { monohydrate } 2.03 \mathrm{mg}\end{array}$ & 0.86 & 0.85 & 0.85 & 0.08 \\
\hline Eldervit-20 & $\begin{array}{l}\text { Folic acid } 5 \mathrm{mg} \text {, methyl cobalmin } 500 \mu \mathrm{cg} \text {, } \\
\text { eicosapentanenoic acid } 90 \mathrm{mg} \text {, docosahexa } \\
\text { nenoic acid } 60 \mathrm{mg} \text {, zinc sulphate monohydrate } \\
22.5 \mathrm{mg} \text {, grapeseed extract } 150 \mathrm{mg} \text {, manganese } \\
\text { sulphate } 2 \mathrm{mg} \text {, mixed carotenes } 10 \% 10.33 \mathrm{mg} \text {, } \\
\text { copper sulphate } 1 \mathrm{mg} \text {, chromium piconalate } \\
65 \mathrm{mcg} \text {, selenium dioxide } 40 \mathrm{mg}\end{array}$ & 0.396 & 0.390 & 0.392 & 1.54 \\
\hline $\begin{array}{l}\text { Antoxid } \\
\text { (Dr. Reddy's } \\
\text { Lab. Hydrabad) }\end{array}$ & $\begin{array}{l}\text { Beta-carotene } 10 \mathrm{mg} \text {, Zinc sulphate } \\
\text { monohydrate } 200 \mathrm{mcg} \text {, manganese sulphate } \\
2.0 \mathrm{mg}\end{array}$ & 0.253 & 0.250 & 0.251 & 1.28 \\
\hline
\end{tabular}

* Average of five determinations; ${ }^{\#}$ Relative standard deviation. 
The method is eco-friendly, as extraction is carried out in $\mathrm{pH}$ medium and has good potential for its use in the determination of $\mathrm{Cu}$ (II) after extraction in organic phase at microgram level.

\section{Acknowledgements}

One of the authors (A.B.S.) thanks the University Grants Commission, New Delhi, for awarding Fellowship under FIP. The authors are also thankful to Dr. T. N. Lokhande for valuable suggestions regarding this work.

\section{References}

1 B. Sarkar, Copper, in Metals in Clinical and Analytical Chemistry, (H.G. Sailer, A. Sigel and H. Sigel, eds.), Marcel Dekker, New York, 1994.

2 I. Scheiber, R. Dringen and J.F.B. Mercer, Effects of Deficiency and Overload, Chapter 11, Copper, Springer, New York, 2013.

3 T.W. Johnson, Mom's low copper could harm newborn, Agric. Res. Mag., 1999, 3, 47.

4 A, Ralf and H.J. McArdle, Copper Metabolism and Requirements in the Pregnant mother, her Fetus and Children, International Copper Association, New York, 2001.

5 P.A. Walravens, Nutritional importance of copper and zinc in neonates and infants, Clin. Chem., 1980, 26, 185-189.

6 B.C. Blake-Coleman, Copper Wire and Electrical Conductors - The Shaping of a Technology, Harwood Academic Publishers, Chur, Switzerland, 1992, 13.

7 M. Soylak, Determination of trace amounts of copper in high purity aluminium samples after preconcentration on an activated carbon column, Fresenius Environ. Bull., 1998, 7, 383-385.

8 N. Pourreza and K. Ghanemi, Determination of copper by flame atomic absorption spectrometry after solid-phase extraction, Spectroscopy Lett., 2006, 39, 127-134.

9 M.A. Taher, S.Z. Moberakeh and A.R. Mohamdesi, Determination of trace copper by FAAS after solid phase extraction and preconcentration on 2-amberlite XAD-2 loaded with nitroso salt, Turk. J. Chem., $2005,29,17-26$.

10 V.K. Jain, S.S. Sait, P. Shrivastav and Y.K. Agrawal, Application of chelate forming resin amberlite XAD-2-o-vanillin thiosemicarbazone to the separation and preconcentration of copper (II), zinc (II) and lead (II), Talanta, 1997, 45, 397-399.

11 G.L. Moore, Introduction to Inductively Coupled Plasma Atomic Emission Spectrometry, Elsevier, New York, 1989, 3, 209-217.

12 Y. Guo, B. Din, Y. Liu, X-Chang S. Meng and J. Liu, Preconcentration and determination of trace elements with 2-aminoacetylthiophenol functionalized Amberlite XAD-2 by inductively coupled plasmaatomic emission spectrometry, Talanta, 2004, 62, 207-213.

13 Y. Liu, P. Liang and L. Guo, Nanometer titanium dioxide immobilized on silica gel as sorbent for preconcentration of metal ions prior to their determination by inductively coupled plasma atomic emission spectrometry, Talanta, 2005, 68, 25-30.

14 A. Ramesh, K. Ramamohan, K. Seshiah and N.D. Kumar, Determination of trace elements by inductively coupled plasma-atomic emission spectrometry (ICP-AES) after preconcentration on a support impregnated with piperidine dithiocarbazone, Anal. Lett., 2001,34(2), 219-229.

15 K.E. Jarvis, A.L. Gray and R.S. Houk, eds., Handbook of Inductively Coupled Plasma Mass Spectrometry, Chapman and Hall, New York, 1992.

16 M. Ince, O. Kaplan and M. Yaman, Solid-phase extraction and preconcentration of copper in mineral waters with 4-(2-pyridyl-azo) resorcinol-loaded amberlite XAD-7 and flame atomic absorption spectrometry, Water Environ. Res., 2008, 80 (11), 2104-2110.

17 M.H. Ramsey, A. Argyraki and M. Thompson, Estimation of sampling bias between different sampling protocols on contaminated land, Analyst, 1995, 120, 1353-1356.

18 D.V. Khasnis and V.M. Shinde, Determination of copper in steel, brass, gun metal, nickel, silver and aluminum alloy by extraction with phenanthraquinone mono thiosemicarbazone, J. Indian Chem. Soc., 1982, 59, 812-814.

19 K.N. Thimmaiah, H.S. Sanke Gowda and M. Ahemed, Spectrophotometric determination of palladium (II) and copper (II) with p-anisaldehyde thiosemicarbazone: analysis of alloys and minerals, Indian J. Chem., 1983, 22, 690-699.

20 V.A. Jadhav and A.G. Vandre, 8-Methoxy-2-chloroquinoline-3- carbaldehyde thiosemi carbazone as an analytical reagent for cobalt (II) and copper (II), J. Indian Chem. Soc., 1995, 72, 747-748.

21 M. Tongsen, L. Menf, H. Cengde, L. Kuaizhi, L. Zhenghao and Z Paxuesuebav, Spectrophotometric study on copper (II) with pyruvaldehyde ( $\mathrm{NN}^{\prime}$-dibutyl) bis-thiosemicarbazone, Ziar, Keruebau, 1999, $31,70-72$.

22 P. Lopez-de-Alba, L. Loper-Martiney and J. Amador-Hernandez, Spectrophotometric determination of copper in medical formulation: wheat bran and drinking water, Bol. Soc. Chil. Quim., 1999, 44, 469-477.

23 K. Janardhan Reddy, J. Rajesh Kumar, S. Lakshmi Narayana, C. Ramachandraiah, T. Thriveni and A. Varada Reddy, N-ethyl-3carbazolecarboxaldehyde-3-thiosemicarbazone: a new extractive spectrophotometric reagent for the determination of copper(II) in environmental and pharmaceutical samples, Environ. Monit. Assess., 2007, 124, 309-320.

24 R.S. Lokhande, S.V. Poman and H.R. Kapadi, Extractive spectrophotometric determination of $\mathrm{Cu}$ (II) with 4-chloro-iso-nitrosoacetophenone thiosemicarbazone, Asian J. Chem., 2001, 13, 1222-1224.

25 M. Sayaji Rao, N.B. Prasad, L. Husain and K. Reddy, Spectrophotometric determination of $\mathrm{Cu}$ (II) in alloys and edible oils using 2-acetylthiophenone thiosemicarbazone, Indian J. Chem., 2006, 45A, 1659-1662.

26 B.K. Reddy, J.R. Kumar, K.J. Reddy, L.S. Sharma and A.V. Reddy, Rapid and sensitive extractive spectrophotometric determination of copper (II) in pharmaceutical and environmental sample using benzyl- $\alpha$-monoxime thiosemicarbazone, Anal. Sci., 2003, 19, 423-428.

27 G.S. Kamble, S.S. Kolekar and M.A. Anuse, Synergistic extraction and spectrophotometric determination of copper (II) using 1-(2', $4^{\prime}-$ dinitroaminophenyl)-4,4,6-trimethyl-1,4-dihydropyrimidine-2thiol: analysis of alloys, pharmaceuticals and biological samples, Spectrochim. Acta Part A: Mol. Biomol. Spectrosc., 2011, 78, 1455-1466.

28 A. Kumar, P. Sharma, L.K. Chandel, B.K. Kala and S.J. Kunsogi-Mate, Synergistic solvent extraction of copper, cobalt, rhodium and iridium into 1,2-dichloroethane at trace level by newly synthesized 25,26,27,28, tetrahydroxy-5,11,17,23-tetra-[4-(N-hydroxyl-3-phenylprop-2-enimidamido) phenylazo] calyx[4] arene, J. Incl. Phenom. Macrocycl. Chem., 2008, 62, 285-292.

29 V. Kaur, A.K. Malik and N. Verma, Derivative spectrophotometric determination of copper and palladium simultaneously by using MDTC as a reagent, Anal. Lett., 2007, 40, 2360-2373.

30 P. Tekale, S. Tekale, S. Lingayat and P. Pabrekar, Extractive spectrophotometric determination of copper (II) using 1-phenyl-1-hydrazonyl-2-oximinopropane-1, 2-dione, Science Research Reporter, 2011, 2, 83-87.

31 S. Padmanabha and V. Suryanarayana Rao, Spectrophotometric determination of trace copper in industrial water after preconcentration with 4-hydroxybenzaldehyde thiosemicarbazone, Water Research and Development, 2011, 1, 63-66.

32 R.A. Nazareth, B. Narayana and N. Shreekumar, Spectrophotometric determination of copper (II) using 4-vanillideneamino-3-methyl-5mercapto-1,2,4-triazole, Indian J. Chem., 2001, 40A, 1016-1018.

33 C. Park, H.-S. Kim and K.-W. Cha, Spectrophotometric determination of copper after selective extraction with $\alpha$-(2-benzimidazolyl)- $\alpha^{\prime}$, $\alpha^{\prime \prime}$-(N-5-nitro-2-pyridylhydrazone) $\mathrm{C}$ toluene in presence of Brij 58 , Bull. Korean Chem. Soc., 1999, 20, 352-354.

34 S. Meng, Z. Jia, K. Wang, Y. Fan and Y. Guo, Spectrophotometric determination of trace copper (II) in biological samples with 2,4-bis(4-phenylazophenylaminodiazo) phenol, J. Ana. Chem., 2014, 60, 357-361.

35 A.S. Aswar and M.D. Joshi, Solvent extraction and spectrophotometric determination of copper (II) with 2-hydroxy-5-methylacetophenoneisonicotinoylhydrazone, Indian J. Chem. Tech., 2008, 15, 79-81.

36 D. Rekha, K. Suvardhan, K. Sureshkumar, P. Reddyprasad, B. Jayraj and P. Chirangeevi, Extractive spectrophotometric determination of copper (II) in water and alloy sample with 3-methoxy-4-hydroxybenzaldehyde-4-bromophenylhydrazone, J. Serb. Chem. Soc., 2007, 72, 299-310.

37 R.S. Lokhande, R.P. Sonawane and U. Chavan, Development of method for extractive spectrophotometric determination of copper (II) with of hydrazine carboxamide-2-[(-2-hydroxy-l-naphthalenyl) methylene] as an analytical reagent, Int. J. Chem. Sci., 2011, 9, 503-509. 
38 A.R. Kocharekar and N.V. Thakkar, Extractive spectrophotometric determination of copper (II) and its applications in pharmaceuticals samples and alloys, J. Sci. Ind. Res., 2004, 63, 283-286.

39 S. K. Jawad, S. K. Ali and S. M. Hammed, Spectrophotometric determination of micro amount of copper (II) in different environmental and vital sample by new organic reagent, Iraqi National J. Chem., 2011, 43, 299-309.

40 R.S. Lokhande, S.P. Janwadkar, S. Kulkarni and S. Patil, Solvent extraction and spectrophotometric determination of copper (II) by using acetophenone-2', $5^{\prime}$ - dihydroxy semicarbazone as an analytical reagent, International J. Pharma Biosci., 2011, 2, 315-319.

41 R.A. Nalawade, A.M. Nalawade, G.S. Kamble and M.A. Anuse, Rapid, synergistic extractive spectrophotometric determination of copper(II) by using sensitive chromogenic reagent $\mathrm{N}^{\prime \prime}, \mathrm{N}^{\prime \prime}$-bis[(E)(4-fluorophenyl) methylidene]thiocarbonohydrazide, Spectrochim. Acta Part A: Mol. Biomol. Spectrosc., 2015, 146, 297-306.
42 K.S. Dhaka, J. Mohan, V.K. Chadha and H.K. Pujari, Heterocyclic systems containing bridge head nitrogen atom: Part XVI - synthesis of s-triazolo $[3,4-\mathrm{b}][1,3,4]$ thiadiazines related heterocycles, Indian J. Chem., 1974, 12, 288-290.

43 A.I. Vogel, A Text Book of Quantitative Inorganic Analysis, 3rd edn., Longmans, London, 1975.

44 Z. Marczneko, Spectrophotometric Determination of Elements, Ellis Horwood Limited, Chichester, 1976, 125.

45 R.A. Robinson and R.H. Stokes, Electrolyte Solutions, 2nd edn., rev., Butterworth, London, 1988, 371.

46 G.H. Ayers, Evaluation of accuracy in photometric analysis, Anal. Chem., 1949, 21(6), 652-657.

47 A. Ringbom, Z. Anal. Chem., 939, 115, 332.

48 E.B. Sandell, Colorimetric Determination of Traces of Metals, 3rd edn., Interscience, New York , 1959, 97. 